\title{
LABORATORY AND CLINICAL STUDIES OF 2-PHENYLALANINE-8-LYSINE VASOPRESSIN (OCTAPRESSIN)
}

\author{
MARY E. HưNTER, M.D., C.M., F.R.C.P.(C) AND \\ R. A. GoRDON, B.SC., M.D., F.R.C.P.(C), F.F.A.R.C.S."
}

\section{INTHODUCTION}

THE RECOGNIZED and well-documented dangers of using epinephrine and similar vasoconstrictors for the production of haemostasis in the presence of cyclopropane and halogenated hydrocarbon anaesthetic agents ${ }^{1-3}$ has given some importance to the search for effective vasoconstrictor substances which do not increase the irritability of the heart and its conducting system. The substance 2-phenylalanine-8-lysine vasopressin (Octapressin) has been presented as a vasoconstrictor which may be used safely in association with such agents, ${ }^{4-6}$ and we have undertaken to investigate this substance from that point of view.

Octapressin is a synthetic derivative of the octapeptide hormone vasopressin which is produced by the posterior pituitary. It possesses powerful vasoconstrictor and pressor properties and has a very low order of toxicity in laboratory animals. It produces contraction of all smooth muscle, including the intestinal musculature, but has very little oxytocic effect. ${ }^{7,8}$ It has a marked pressor effect and somewhat constricts the coronary arteries. ${ }^{9-11}$ The coronary effect is reported to be less than that of vasopressin. The pulmonary wedge pressure is increased; and the arterio-venous oxygen difference for the systemic circulation is increased. Intravenous injection in fairly high doses causes intense vasoconstriction in the splanchnic region, leading to a marked lowering of pressure in the portal vein. ${ }^{12-14}$ Its antidiuretic effect is reported to be much less than that of vasopressin and angiotensin. ${ }^{15}$

On injection, Octapressin produces a local ischaemia without the secondary dilatation and capillary stasis which is a feature of such ischaemia produced by epinephrine. ${ }^{16}$ Reports in the European literature have established that it is a satisfactory vasconstrictor for combination with local anaesthetics, particularly in otolaryngology and gynaecology. ${ }^{17-22}$

Hugin has reported the intravenous administration of considerable quantities of this substance to patients anaesthetized with halothane and cyclopropane. with no evidence of cardiac disturbance. ${ }^{4}$

\section{LABORATORY STUDY}

Before applying this drug to anaesthetized patients, we investigated its effect on cardiac rhythm during halothane anaesthesia and cyclopropane anaesthesia in cats. The cats were chosen because previous investigators had reported the

-Department of Anaesthesia, University of Toronto.

Can. Anaes. Soc. J., vol. 13, no. 1, January, 1966 
HUNTER \& GORDON: 2-PHENYLALANINE-8-LYSINE VASOPRESSIN (OCTAPRESSIN) 41

effects of the drug in this animal, and perfusion of isolated cat hearts had demonstrated that a relatively large dose of the substance is required to produce coronary vasoconstriction and deleterious effects on the heart. It appears therefore that, in the cat, any cardiac effects observed would probably be due to the combination of Octapressin with the anaesthetic agent rather than to the Octapressin alone.

\section{METHOD}

Six adult cats were anaesthetized with thiopentone, nitrous oxide, oxygen, and halothane. The trachea was then intubated with a Portex oral tube, and a vein was cannulated. Increasing doses of Octapressin were injected through the intravenous canula in the order shown in Figure 1. The electrocardiogram was recorded at 1, 2, 3, and 5 minutes after each injection. At the end of each experiment a solution of adrenaline was injected intravenously in increasing doses until ventricular disturbances were produced. This was considered essential in order to prove that the cats would show ventricular arrhythmia in response to the injection of adrenaline under these circumstances.

\section{INJECTION CODE}

\section{Octapressin}

Dilution: 5 pressor units in 30 c.c. nermal salina.

\section{I.V. INECTION}

(I) 0.5 c.c.

(2) 1.0 c.c.

(3) 1.5 c.c.

(4) 2.0 c.c.

(5) 3.0 c.c.

(6) 6.0 c.c.

(7) 0.5 c.c. full strength $=2.5$ pressor units

(9) 1.0 c.c. full strength $=5.0$ pressor units

\section{Adrenaline solution $1 / 50,000$}

(9) 0.25 c.c.

(10) 0.5 c.c.

\section{E.C.G. RECORD} AFTER EACH INJECTION
A. i minute
B. 2 minutes
C. 3 minutes
D. 5 minutes

Frgune 1. Injection code for cat experiments

\section{Tecennque}

Our aim was to simulate the normal course of anaesthesia for human patients as closely as possible.

Premedication was not given, since the effects of narcotics are species specific and would not be similar in the cat and in man, and because many different regimes of premedication are in common use clinically. It might moreover be 
presumed that, if premedication is assumed to protect the heart from arrhythmias, human subjects so premedicated would under the same conditions be even less likely to develop cardiac disturbances than the cats.

The cats were kept for one to two weeks after delivery to assure that they were in good health.

Initially we attempted to locate a vein in order to induce anaesthesia with thiopentone. This had to be abandoned as the cats were too wild to tolerate the attempt without endangering the workers. They were therefore first anaesthetized with halothane. While the cat was held firmly, a face mask was placed over the head and induction was accomplished with $3-5$ per cent of halothane vapour. When the animal relaxed, the long saphenous vein was exposed on one leg by shaving with electric clippers and wiping the skin with xylol. With an assistant compressing the vein with his thumb in the groin, a polythene catheter was inserted through a puncture hole in the vein made by a $\# 18$ thin-walled needle. A \#23 Luer-Lok needle was attached to the distal end of the catheter for injections. The halothane was then turned off, and 1 to 2 c.c. of 2.5 per cent thiopentone solution was given to all cats at the time of intubation. The cats were breathing spontaneously at this time.

Intubation was accomplished by passing a \#1 or \#2 Portex oro-tracheal tube into the trachea under direct vision after spraying the pharynx and cords with 4 per cent lidocaine solution. This topical spray was found to make the difference between success and failure in intubation. The tube was then connected to an Ayre's T-piece system, and four litres of 50 per cent each of nitrous oxide and oxygen was delivered through a Fluotec Vaporizer. Spontaneous respiration was maintained. The animal was then connected to the electrocardiograph using needle electrodes. A chest lead over the apex beat was found to give the best tracing, and was used in all animals. This was considered to be lead V4.

The schedule of injections of Octapressin solution was then commenced (Fig. 1) and cardiac action was monitored.

The same cats were anaesthetized with cyclopropane one month later and the same procedure was followed except that a $\# 60$ Ohio infant circle absorber was used.

\section{Results}

Six cats were maintained on halothane anaesthesia for periods varying from one hour to three hours and at halothane concentrations varying from 0.75 to 1.25 per cent. The only cardiac disturbance noted was sinus arrhythmia, which appeared very definitely on all tracings. All six cats showed electrocardiographic disturbances on the injection of adrenaline at the end of the anaesthetic period. All recovered spontaneously and survived. Figure 2 shows a typical electrocardiogram after the eighth intravenous injection of Octapressin, giving a total of 5 pressor units. Figure 3 shows the reaction to the intravenous injection of 1 c.c. of $1 / 50,000$ adrenaline solution.

The same six cats were anaesthetized with cyclopropane one month after the halothane series. The technique was essentially similar to that described for halothane. Anaesthetic time varied from one hour to one hour and fifteen minutes. On two occasions the recording equipment ceased to function before the injection 




Figure 2. Typical ECG tracing showing normal cardiac rhythm after injection of 5 pressor units of Octapressin in the cat under halothane anaesthesia.

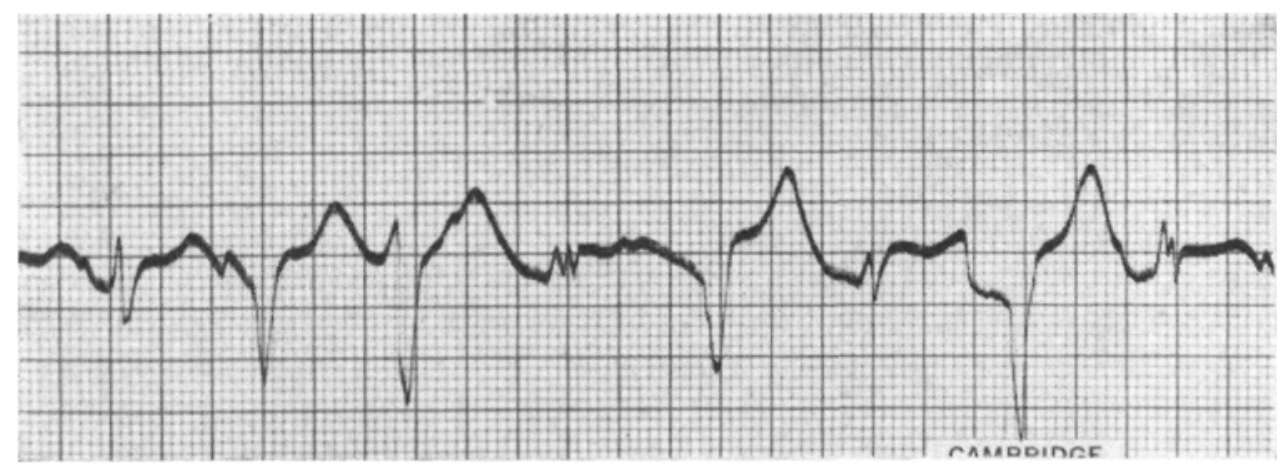

Ficure 3. Typical arrhythmia after intravenous injection of 1 c.c. of $1 / 50,000$ adrenaline in the cat under halothane anaesthesia.

schedule was completed, but in neither case was an arrhythmia recorded following the injections of Octapressin up to the time of equipment failure. The experiment was completed in the other four cats. No cardiac irregularities occurred with injections of Octapressin, but in each case ventricular arrhythmias were produced by injection of 0.5 c.c. of $1 / 50,000$ adrenaline solution. Figure 4

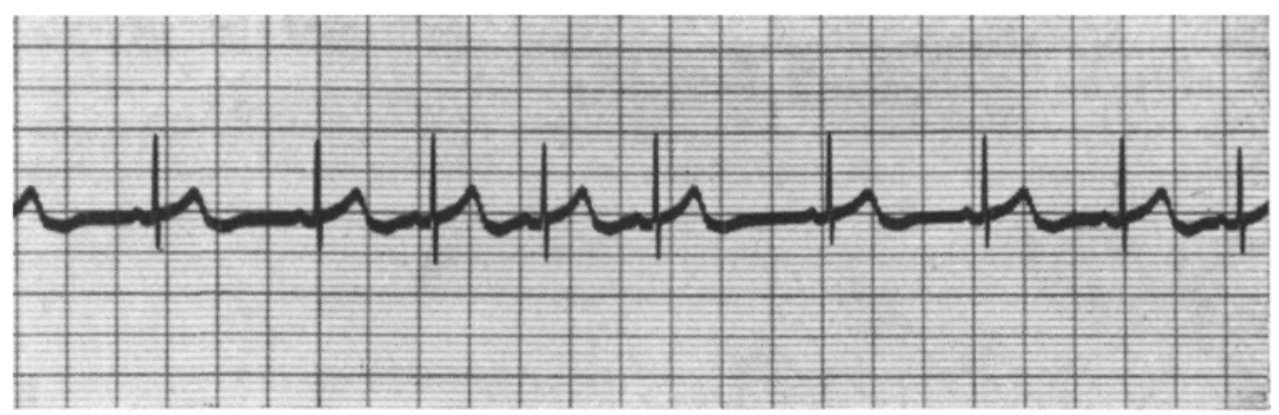

Figure 4. Typical ECG tracing following Octapressin injection schedule in a cat anaesthetized with cyclopropane. 
is a typical electrocardiographic tracing following the completion of the injection of five pressor units of Octapressin. Figure 5 is a typical tracing twelve seconds after the injection of 0.5 c.c. of $1 / 50,000$ adrenaline.

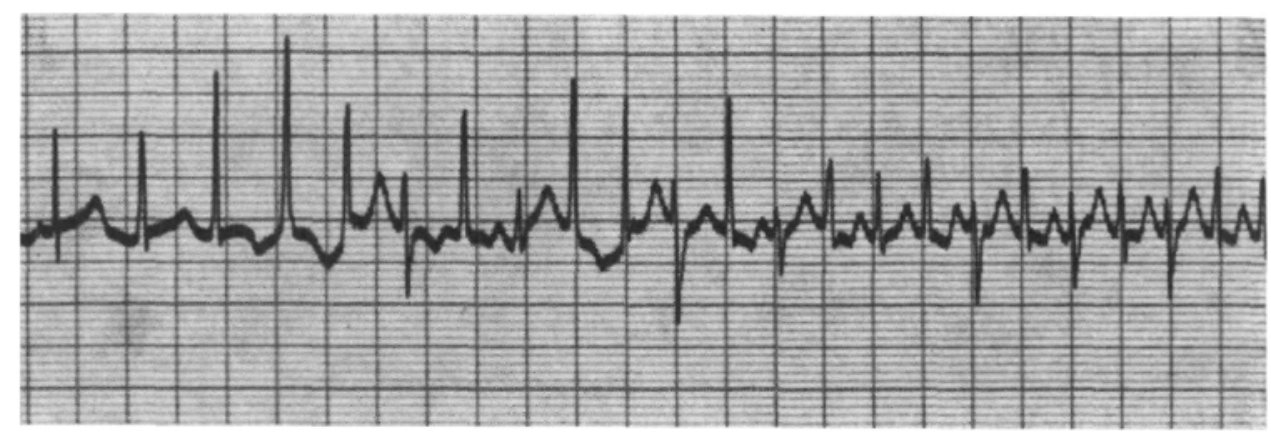

Figure 5. Typical arrhythmia following injection of adrenaline at the end of the experiment in a cat under cyclopropane anaesthesia.

\section{Clunical Study}

Following the laboratory demonstration of the stability of cardiac rhythm during injection of Octapressin under halothane and cyclopropane anaesthesia, Octapressin was substituted for adrenaline and neosynephrine in the local anaesthetic solutions injected in gynaecological, octolaryngological, plastic surgery, and orthopaedic patients for the production of haemostasis. At the present time it has been used in 32 cases in association with halothane anaesthesia, and in two patients anaesthetized with cyclopropane. Injections have been made into the nasal septum, the face, the perineum, and the muscles of the back. The quantities thus injected have varied from 0.4 to 5 pressor units. Concentrations used have varied from 5 pressor units in 30 c.c. of local anaesthetic solution to 10 pressor units in 25 c.c.

Lead II of the E.C.G. was observed on a cardioscope in 20 cases, and a continuous written recording of lead III was made on a Grass polygraph in the remaining 12 cases.

In three cases arrhythmias occurred. In each case these were regular ventricular extrasystoles which appeared with coughing on an endotracheal tube. It is interesting that they were not detectable by palpation of the peripheral pulse. In two of these cases the extrasystoles occurred before injection of the Octapressin. The third patient was a stout lady presented for vaginal repair, in whom there was difficulty in maintaining adequate ventilation in the lithotomy position. We cannot be sure in this case what role the drug may have had in the production of the arrhythmia, but since tracheal stimulation and hypercapnoea are known to produce this arrhythmia, we are inclined to believe that its occurrence was not related to use of the drug in any instance.

We have also used Octapressin in a concentration of 10 pressor units in 25 c.c. of solution for topical application to reduce bleeding during sub-mucous 
resection of the nasal septum. While it is impossible under these circumstances to estimate the quantity absorbed, its use in this manner has not disturbed cardiac rhythm.

Six patients only showed a slight rise in blood pressure, the greatest of these being from $120 / 80 \mathrm{~mm}$. $\mathrm{Hg}$ to $140 / 90 \mathrm{~mm}$. $\mathrm{Hg}$.

\section{Conctuston}

While the number of clinical cases in the present study does not permit us to state dogmatically that the use of phenylalanine lysine vasopressin (Octapressin) is entirely devoid of danger in the presence of halothane or cyclopropane anaesthesia, we feel that the evidence presently accumulated certainly suggests that this may be true.

\section{SUMMARY}

The recognized and well-documented dangers of using epinephrine and similar vasoconstrictors for the production of haemostasis in the presence of cyclopropane and halogenated hydrocarbon anaesthetic agents gives importance to the search for effective vasoconstrictor substances which do not increase the irritability of the heart and its conducting system. Octapressin (2-phenylalanine8-lysine-vasopressin) has been presented as a substance which may be safely used in association with such agents.

The influence of Octapressin on cardiac rhythm was studied by intravenous injection into cats anaesthetized with halothane and cyclopropane. The injection of pressor units of Octapressin failed to produce any electrocardiographic disturbances, but in each case injection of 1 c.c. of 1/50,000 Adrenaline solution at the conclusion of the experiment produced ventricular arrhythmia.

Octapressin was used by injection for the production of haemostasis in the presence of halothane in 30 cases and of cyclopropane in 2 cases during surgical operation. Cardiac rhythm was monitored on lead II of the electrocardiogram, and in no case did any arrhythmia appear which could be attributed to the use of the vasoconstricting agent. This experience in the laboratory and in clinical surgery suggests that Octapressin may be safely used as a local vasoconstricting agent in the presence of halothane and cyclopropane.

\section{RÉSUMÉ}

Les risques connus et bien prouvés de se servir d'épinéphrine et de vasoconstricteurs semblables pour produire l'hémostase en présence du cyclopropane et d'agents anesthésiques d'hydrocarbone halogéné donnent de l'importance à la recherche de substances vasoconstrictives efficaces qui n'augmentent pas l'irritabilité du coeur et de son système de conduction. L'octapressine (2-phénylalanine-8-lysine vasopressine) nous a été présentée comme une substance qui peut être employée en association avec ces agents et cela en toute sécurité.

Nous avons étudié les effets de loctapressine sur le rythme cardiaque en 
linjectant dans les veines de chats anesthésiés avec de l'halothane et du cyclopropane. L'injection de 5 unités d'octapressine n'a pas réussi à produire de troubles électrocardiographiques, mais dans chaque cas l'injection de 1 c.c. d'adrénaline à 1/50000 à la fin de l'expérience a produit de l'arythmie ventriculaire.

L'octapressine a été utilisée en injection pour aider à l'hémostase en présence d'halothane chez 30 malades et de cyclopropane chez 2 malades au cours d'interventions chirurgicales. Nous avons enregistré le rythme cardiaque en $2^{\text {tme }}$ dérivation et en aucun cas nous n'avons dépisté des arythmies qui auraient pu être attribuées à l'agent vasoconstricteur. Cette expérience tant en laboratoire qu'en clinique nous laisse croire que l'octapressine peut être employée sans danger comme agent vasoconstricteur local en présence de l'halothane et du cyclopropane.

\section{REFERENCES}

1. Rogoman, E. P.; Johnson, A. E.; \& Conn, A. W. The Use of Epinephrine during Halothane Anaesthesia with Respect to Ventricular Irritability in Dogs: A Preliminary Report. Anesth. \& Analg. 42: 109 (1963).

2. BRINDLE, G. F.; GLbert, R. G. B.; \& MLlaR, R. A. The Use of Fluothane in Anaesthesia for Neurosurgery: A Preliminary Report. Canad. Anaesth. Soc. J. 4: 265 (1957):

3. Rosen, M. \& ROE, R. B. Adrenaline Infiltration during Halothane Anaesthesia: A Report of Two Cases of Cardiac Arrest. Brit. J. Anaesth. 35: 51 (1963).

4. Hucns, W. Die Verträglichkeit von Octapressin mit verschiedenen Narkosen. Anaesthesist. 11: 185 (1962).

5. SHANKS, G. A. Intravenous Octapressin during Halothane Anaesthesia: A Pilot Study. Brit. J. Anaesth. 35: 640 (1963).

6. The Compatibility of Octapressin with Cyclopropane, Trilene, and Halothane. New Zealand M. J. 63: 156 (1964).

7. BERDE, B.; DoEprnNer, W.; \& KonzETr, H. Some Pharmacological Actions of Four Synthetic Analogues of Oxytocin. Brit. J. Pharmacol. 12: 209 (1957).

8. Berde, B.; CerletTr, A.; \& KonzetT, H. The Biological Activity of a Series of Polypeptides Related to Oxytocin. Presented to a "Symposium on Oxytocin" in Montevideo, August 17-19, 1959.

9. Tsakmis, A. \& BuHLManN, A. Kreislaufwirkungen eines neuen synthetischen Vasopressins. Deutsche med. Wchnschr. 88: 46 (1963).

10. Rubot, S.; Agramowttz, S.; KelhoFfer, W. S.; Green, H.; Small, M. J., \& Schwartz, I. Cardiovascular Effects of Phenylalanyl-2-lysyl-8-Vasopressin (PLV-2) Am. J. of M. Sc. 246: 137, 479 (1963).

11. Scemmot, L.; Bernauer, W.; \& Menzer, H. Die Wirkung von Phenylalanin-2-lysin-8Vasopressin und Lysin-8-Vasopressin auf Coronardurchblutung des Hundes und den Ratenuterus. Arzneimittel-Forsch. 12: 1019 (1962).

12. Tsakmis, A. \& BUHLMaNN, A. Experimentelle Untersuchungen beim Menschen über die Wirkung von Vasopressin auf die Lederdurchblutung und den portalen Druck. Schweiz. med. Wchnschr. 92: 147 (1962).

13. Tsarmis, A.; Haemmerrl, U. P.; \& Burinmann, A. Reduction of Portal Venous Pressure in Cirrhotic Patients with Bleeding from Oesaphageal Varices, by Administration of a Vasopressin Derivative, Phenylalanine-Lysine-Vasopressin Am. J. Med. 36: 825 (1964).

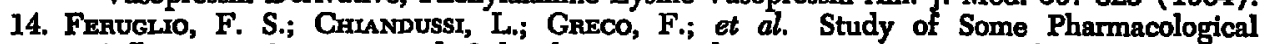
Effects on Systemic and Splanchnic Hemodynamics: II. Action of Octapressin in Normal and Cirrhotic Humans. Minerva med. 54: 3114 (1963).

15. LoNGo, L. D.; MORres, J. A.; SMTTH, R. W.; BECK, R.; \& Assair, N. S. Hemodynamic and Renal Effects of Octapressin. Proc. Soc. Exper. Biol. \& Med. 115: 760 (1964).

16. KLeingenstrom, $P$. \& Westermari, $L$. Local Effects of Adrenaline and PLV-2 in Local Anaesthesia. Acta anaesth. Scandinav. 7: 131 (1963). 
HUNTER \& GORDON: 2-PEENYLALANINE-8-LYSINE VASOPRESSIN (OCTAPRESSIN) 47

17. Mrssura, T. \& WEDER, A. Vergleichende Untersuchungen über das Verhalten des Kreislaufes bel der Tonsillektomie in LA mit vasokonstriktorischem Zusatz von Adrenalin bzw. PLV-2. Pract. oto-rhino-laryng. 24: 249 (1962).

18. Bozrobas, B. Oto-rhino-laryngologische Erfahrungen mit Octapressin. Wein. med. Wchnschr. 113: 277 (1963).

19. DE Grenus, E. Die Kreislaufstabilisierung bei der Tonsillektomie in Lokalanesthesie (Ersatz des Adrenaline durch Octapressin). Pract. oto-rhino-laryng. 25: 145 (1963).

20. Hocrurr, E. Klinische Erfahrungen mit der lokalen Anwendung von Octapressin in der Gynakologie und in der Geburtshilfe. Schweiz. med. Wchnschr, 92: 654 (1962).

21. HochuLr, E. \& KäsER, $O$. The Use of Octapressin as a Local Hemostatic in Obstetrics and Gynecology. Triangle. 5: 363 (1962).

22. Chackers, J. A. The Use of a New Synthetic Vasoconstrictor (PLV-2) in Gynaecological Surgery. Third World Congress of the International Federation of Gynecology and Obstetrics. Vienna, September 3-9, 1961. 